\title{
Upaya Pengelolaan dan Pemberdayaan Masyarakat Guna Meningkatkan Hasil Laut Desa Ulee Blang Kec. Idi Rayeuk pada KKN Tematik Universitas Samudra 2021
}

\section{Noni Wardani*1, Aulia Zulhaiqal Putra ${ }^{2}$, Sulaiman Saputra ${ }^{3}$, Ellida Novita Lydia ${ }^{4}$}

\author{
1,2,3,4Teknik Sipil, Fakultas Teknik, Universitas Samudra, Indonesia \\ *e-mail: noniwardani87@gmail.com ${ }^{1}$, auliazulhaiqal10@gmail.com ${ }^{2}$, saputrasulaiman0808@gmail.com ${ }^{3}$
}

\begin{abstract}
Abstrak
Pemberdayaan mayarakat merupakan kegiatan partisipasi masyarakat dalam pemenuhan kebutuhan hidup dan menyelesaikan permasalahan yang dialami masyarakat. Kegiatan dilaksanakan melalui program Kuliah Kerja Nyata (KKN) Tematik yang merupakan aktivitas berbasis pengabdian masyarakat untuk meningkatkan empati mahasiswa terhadap kondisi masyarakat dan lingkungannya. KKN ematik Unsam 2021 dilaksanakan di Desa Ulee Blang, Kecamatan Idi Rayeuk, Kabupaten Aceh Timur dengan metode pengabdian seperti sosialisasi pendidikan dan pelatihan teknologi. Dengan adanya KKN Tematik di Desa Ulee Blang, Kecamatan Idi Rayeuk bertujuan mewujudkan potensi masyarakat melalu upaya pengelolaan masyarakat dan pemberdayaan guna meningkatkan hasil laut masyarakat Desa Ulee Blang. Hasil menunjukan adanya respon positif dari perangkat desa dan masyarakat Desa Ulee Blang terhadap kegiatan ini. Selain itu beberapa luaran yang dihasilkan dari program utama dan program pendukung. Dari program utama berupa produk kerupuk udang. Dan dari program pendukung berupa, plang penunjuk arah, website desa, cenderamata, dan logo kemasan produk. Disisi lain terjadi peningkatan kedisiplinan dan partisipasi peserta mahasiswa/i KKN dan masyarakat, dengan melihat keberhasilan berupa luaran beberapa produk yang dihasilkan berupa kerupuk udang.
\end{abstract}

Kata kunci: Desa Ulee Blang, KKN Tematik, Pemberdayaan Masyarakat, Unversitas Samudra

\begin{abstract}
Community empowerment is an activity of community participation in meeting the needs of life and solving problems experienced by the community. The activity is carried out through the Thematic Real Work Lecture (KKN) program which is a community service-based activity to increase student empathy for the condition of society and its environment. The 2021 Unsam Thematic Community Service Program will be held in Ulee Blang Village, Idi Rayeuk District, East Aceh Regency with service methods such as education socialization and technology training. With the Thematic Community Service Program in Ulee Blang Village, Idi Rayeuk District, it aims to realize the potential of the community through community management and empowerment efforts to increase the marine products of the Ulee Blang Village community. The results showed a positive response from the village apparatus and the people of Ulee Blang Village to this activity. In addition, several outputs are produced from the main program and supporting programs. From the main program in the form of shrimp cracker products. And from the supporting programs in the form of signposts, village websites, souvenirs, and product packaging logos. On the other hand, there has been an increase in the discipline and participation of KKN student participants and the community, by looking at the success of several products produced.
\end{abstract}

Keywords: Community Empowerment, Samudra University, Thematic Community Service Program, Ulee Blang Village

\section{PENDAHULUAN}

Desa Ulee Blang, Kecamatan Idi Rayeuk memiliki tambak udang yang mempunyai potensi untuk dikembangkan menjadi produk khas desa. Desa Ulee Blang berada di lokasi yang strategis dimana terletek di pinggiran pantai Objek Wisata Syariah yang bersebelahan dengan desa Tanjung Kapai, desa Alue Dua Muka 0, dan desa Keutapang Mameh. Dengan potensi yang ada berupa hasil tambak udang, udang yang tidak dapat dijuan dapat dikembangkan menjadi produk khas desa yang memiliki cita rasa gurih dan renyah. Konsep pengelolaan dan pemberdayaan masyarakat seperti ini tentunya akan memberikan nilai positif dan edukasi bagi 
masyarakat sekitar. Selain dapat menambah kegiatan untuk program ibu-ibu PKK desa. Hasil dari kegiatan ini dapat dijadikan suatu penghasilan sampingan bagi masyarakat sekitar. Permasalahan inilah yang menjadi dasar untuk memberdayakan masyarakat melalui Kuliah Kerja Nyata dengan mengangkat tema "Upaya Pengelolaan Dan Pemberdayaan Msyarakat Guna Meningkatkan Hasil Laut".

Pemberdayaan atau pemberkuasaan (empoworment) berasal kata "Power" (kekuasaan atau keberdayaan) (Ii et al., 2012). Pemberdayaan masyarakat merupakan upaya meningkatkan partisipasi masyarakat dalam rangka memenuhi kebutuhan hidup dan menyelesaikan permasalahan yang dialami masyarakat dan dilakukan berdasarkan kearifan dan potensi lokal. Serta upaya peningkatan keterampilan melalui pelatihan mengelola sumberdaya alam secara berkelanjutan.

Sinergitas pemerintah daerah, perguruan tinggi, swasta, dan masyarakat menjadi salah satu kunci keberhasilan program pengabdian masyarakat. Perguruan tinggi menjadi instrumen utama dalam melahirkan kualitas sumberdaya anak bangsa yang kreatif dan inovatif. TriDharma Perguruan Tinggi melalui eksistensi pendidikan, penelitian, dan pengabdian masyarakat kemudian menjadi bingkai pengembangan IPTEK dikemas dalam kegiatan KKN (Kurnia et al., 2020).

KKN adalah suatu bentuk pendidikan dengan cara memberikan pengalaman belajar kepada mahasiswa untuk hidup di tengah masyarakat, secara langsung mengidentifikasi dan menangani permasalahan masyarakat serta upaya meningkatkan isi dan bobot pendidikan bagi mahasiswa serta untuk mendapatkan nilai tambah yang lebih besar bagi pendidikan tinggi. Bagi perguruan tinggi penyelenggaraan KKN dilaksanakan dengan maksud meningkatkan relevansi pendidikan tinggi dengan perkembangan dan kebutuhan masyarakat akan IPTEK dan Seni untuk melaksanakan pembangunan serta meningkatkan persepsi mahasiswa tentang relevansi antara materi kurikulum di kampus dengan realita pembangunan dalam masyarakat (Margolang, 2018).

Adapun sasaran dan manfaat penyelenggaran KKN bagi Mahasiswa dan Perguruan Tinggi adalah:

a. Bagi mahasiswa: (a) memperdalam cara berpikir dan bekerja secara interdisipliner; (b) menghayati dan mengerti kesulitan yang dihadapi oleh masyarakat; dan (c) melatih mahasiswa sebagai dinamisator dan problem solver.

b. Bagi Perguruan Tinggi: (a) memperoleh umpan balik sebagai hasil perintegrasian mahasiswa dengan masyrakat; (b) melalui kegiatan mahasiswa, dapat menelaah dan merumuskan kondisi nyata bagi pengembangan IPTEKS; (c) meningkatkan, memperluas dan mempererat kerja sama dengan instansi serta departemen lain melalui rintisan kerjasama mahasiswa yang melaksanakan KKN.

c. Bagi Masyarakat: (a) memperoleh ilmu dalam mengolah hasil lautnya; (b) memberi pengalaman dalam menggali serta menumbuhkan potensi masyarakat sehingga mampu berpastisipasi aktif dalam kegiatan ini; (c) meningkat ekonomi masyarakat melalui program pemberdayaan masyarakat berupa pembuatan kerupuk udang.

\section{METODE}

\subsection{Waktu dan Tempat}

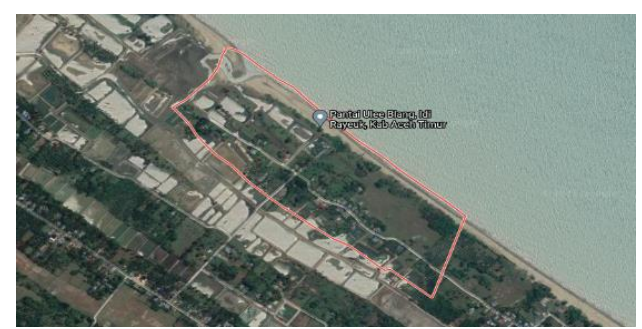

Gambar 1. Peta lokasi KKN Tematik Unsam 2021 di Desa Ulee Blang Sumber: https://uleeblang.atjehtimur.com/ 
Kegiatan pengabdian masyaraka dalam bentuk KKN Tematik ini dilaksanakan selama 45 hari pada bulan Agustus 2021, bertempat di Desa Ulee Blang Kecamatan Idi Rayeuk Kabupaten Aceh Timur. Desa Ulee Blang merupakan desa yang dimana mayoritasnya adalah islam dan memiliki 251 jumlah penduduk, dengan mata pencaharian utama adalah Nelayan.

\subsection{Khayalak Sasaran}

Masyarakat umum, Anak Sekolah (SD, SMP, SMK) Desa Ulee Blang Kecamatan Idi Rayeuk Kabupaten Aceh Timur dan sasaran khusus Kelompok Usaha adalah ibu-ibu.

\subsection{Metode Pelaksanaan}

Metode pelaksanaan pengabdian yang terimplementasi dalam program-program kerja. Metode pengabdian dibuat secara terpadu meliputi penyuluhan, pelatihan, demonstrasi dan pendampingan kelompok. Program kerja KKN Tematik Unsam 2021 di Desa Ulee Blang terbagi dua yaitu program kerja utama dan program kerja pendukung. Berikut program kerja serta teknik pelaksanaannya dapat dilihat pada tabel dibawah ini:

1. Program kerja utama

Untuk teknik pelaksanaan program kerja utama yang diberi judul "pengelolaan hasil laut berupa pembuatan kerupuk udang dari hasil tambak di desa Ulee Blang". Adapun beberapa tahap pelaksanaan pembuatan kerupuk udang yaitu:

a. Persiapan, yaitu berupa penyediaan bahan-bahan dan alat-alat untuk pembuatan kerupuk udang.

b. Pengelolaan, yaitu berupa mengelola bahan-bahan yang sudah disediakan mulai menggiling udang dan semua bumbu hingga halus, mencampur semua adonan yang sudah halus ke dalam tepung ketan, setelah itu di bungkus dengan daun pisang berbentuk seperti lontong dan dikukus selama 30 menit, lalu di dinginkan di dalam kulkas dan di potong tipis-tipis setelah keras lalu di jemur hingga kering dan siap santap.

c. Pengemasan dan pemasaran, yaitu berupa kegiatan untuk memberi wadah atau pembungkus suatu produk dengan tujuan melindungi dan mencegah adanya kerusakan atas produk yang di jual, lalu pemasaran yaitu berupa kegiatan yang memperkenalkan produk melalui sosial media seperti Facebook, Instagram, dan website desa Ulee Blang.

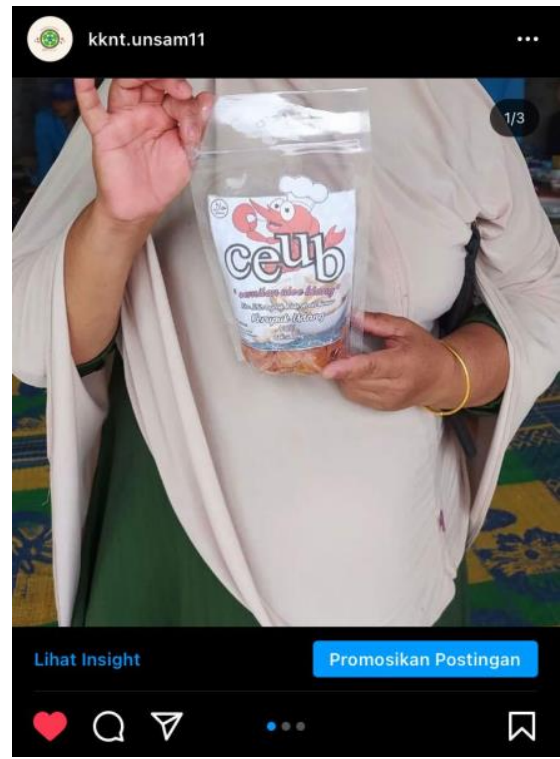

Gambar 2. Bentuk Promosi Instagram

d. Sosialisasi, yaitu berupa kegiatan pemahaman tentang cara pembuatan kerupuk bersama masyarakat Ulee Blang guna memberikan ilmu dan manfaat masyarakat apabila mereka ingin membuat kerupuk. 
2. Program Kerja Pendukung

Tabel 1. Program Kerja Pendukung

\begin{tabular}{cl}
\hline No & Rencana ProgramKerja \\
\hline 1 & Pesisir Mengajar \\
2 & Penanaman Mangrove \\
3 & $\begin{array}{l}\text { Pelatihan Microsoft } \\
\text { office }\end{array}$
\end{tabular}

4 Desain Kemasan danLogo Produk

5 Website Sistem Informasi \& Pemasaran

6 Sosialisasi Teknik pemasaran dengan merancang sistem penjualan

7 Plang penunjuk arah pada desa

8 Optimalisasi Mesinkincir air

9 Pembuatan Rak Buku dari besi

\section{Bakti sosial}

11 Peramalan Jumlah Hasil Tambak Udang

12 Perayaan HUT RI ke- 76

13 Perawatan Tugu

\section{Teknik Pelaksanaan}

Mengajarkan ilmu pada anak yang berusia di bawah 14 tahun dengan tujuan meningkatkan sumber daya manusia didesa Ulee Blang

Melakukan Penanaman Mangrove pada Kawasan tambak di Desa Ulee Blang. Guna meningkatkanekologi lahan basah dan penghijauan desa Ulee Blang.

Melakukan pelatihan microsoft office seperti excel, word, dan power point pada anak yang berusia di atas 14 tahun untuk mempersiapkan akan pengetahuan dan kemampuan di bidang teknologi dan juga meningkatkansumber daya manusia di Desa Ulee Blang

Membuat Kemasan dan Logo untuk Produk Kerupuk Udang menggunakan aplikasi Corel Draw. Guna untuk label atau sebagai indetitas produk dari desa Ulee Blang Membuat Website desa Ulee Blang menggunakan pemograman web. dengan tujuan Untuk Memberikan Informasi profil desa maupun data data yang ada pada desa dan juga memasarkan produk kerupuk udang Untuk Teknik Pemasaran kita menggunakan media dunia maya yang di mana bisa di lihat di oleh banyak orang di berbagai daerah

Pembuatan Plang ini di buat dari kayu dan papan yg dicat lalu dibentuk tulisan, untuk perletakkan berdasarkan data dan arahan dari kepala desa yang bertujuan agar memudahkan pendatang yang datang ke desa Ulee Blang Mengoptimalkan mesin yang sudah rusak atau memperbaiki mesin kincir air pada tambak udang desa Ulee Blang dengan cara memperbaiki komponen-komponen yang rusak dan memberikan pelumas roda pasa mesin kincir air

Pembuatan rak buku ini dibuat yang berbahan dasar dari besi, dengan teknik pengelasan lalu di bentuk mejadi tempat penyimpanan buku

Mahasiswa/i KKNT Fakultas Teknik Universitas Samudra tahun 2021 melakukan pembersihan tempat ibadah, dan juga tempat pengajian atau TPA

Peramalan Jumlah Hasil Tambak Udang ini dilakukan menggunakan SPSS dan dengan cara pengumpulan data yang diambil dari data Panen 10 Tahun kebelakang.

Membuat Kegiatan perayaan HUT RI ke-76 yang berada di lokasi lapangan bola kaki desa Ulee Blang, yangdiikuti oleh anak-anak dan masyarakat desa Ulee Blang. adapun perlobaannya yaitu : tarik tambang, estafet air, makan kerupuk, paku dalam botol, lompat karungdan guli dalam sendok yang bertujuan merayakan kemerdekaan dan juga meningkatkan kebersamaan dan persatuaan yang ada di

Desa Ulee Blang.

Perawatan ini dilakukan dengan cara melakukan 


\begin{tabular}{clc}
\hline & Selamat Datang di Gampong \\
Ulee Blang & pengecatan ulang Tugu Selamat Datang di Gampong Ulee \\
14 & $\begin{array}{l}\text { Pemasangan Bannerprofil } \\
\text { desa Ulee Blang }\end{array}$ & $\begin{array}{c}\text { Pemasangan Banner ini dilakukan dari mulai mendesain } \\
\text { sampai dengan mencetak Spanduk. Lalu kemudian }\end{array}$ \\
15 & Pembuatan cenderamata & melakukan pemasangan Spanduk di Desa Ulee Blang. \\
& & Membuat Kenang - kenangan kepada Geuchik, Teungku \\
& Imum dan Juga TPA berupa sertifikat dan bingkai Foto \\
& Bersama dengan masyarakat Ulee Blang. sebagai Tanda \\
& terima kasih yang telah menerima Mahasiswa Unsam untuk \\
& melakukan KKN-T di Desa tersebut \\
\hline
\end{tabular}

\section{HASIL DAN PEMBAHASAN}

Program kerja dibuat dan dilaksanakan untuk memecahkan berbagai masalah yang dihadapi oleh masyarakat. Program kerja tersebut dilaksanakan serentak dan berjalan secara bersamaan di Desa Ulee Blang. Program kerja keseluruhan terealisasikan semua dengan baik, berikut program kerja yang berhasil dan terealisasi pada KKN Tematik Unsam 2021 di Desa Ulee Blang Kecamatan Idi Rayeuk Kabupaten Aceh Timur:

\subsection{Program Kerja Utama, Yaitu Pembuatan Kerupuk Udang}

Pada program ini kegiatan yang dilaksanakan adalah sosialisasi terkait pembuatan kerupuk udang yang bertujuan untuk meningkatkan ilmu pengetahuan dan kreatifitas masyarakat dalam mengelola hasil laut nya. Sosialisasi dilakukan pada tanggal 23 agustus 2021 pukul 14.00-16.00. Pada program ini di tujukan untuk seluruh ibu-ibu rumah tangga Desa Ulee Blang. Pencapaian pada program ini dikategorikan tercapai yaitu terkumpulnya 15 orang ibuibu rumah tangga dalam sosialisasi ini. Persentase pada program ini adalah $100 \%$ yaitu dapat dikatakan berhasil.
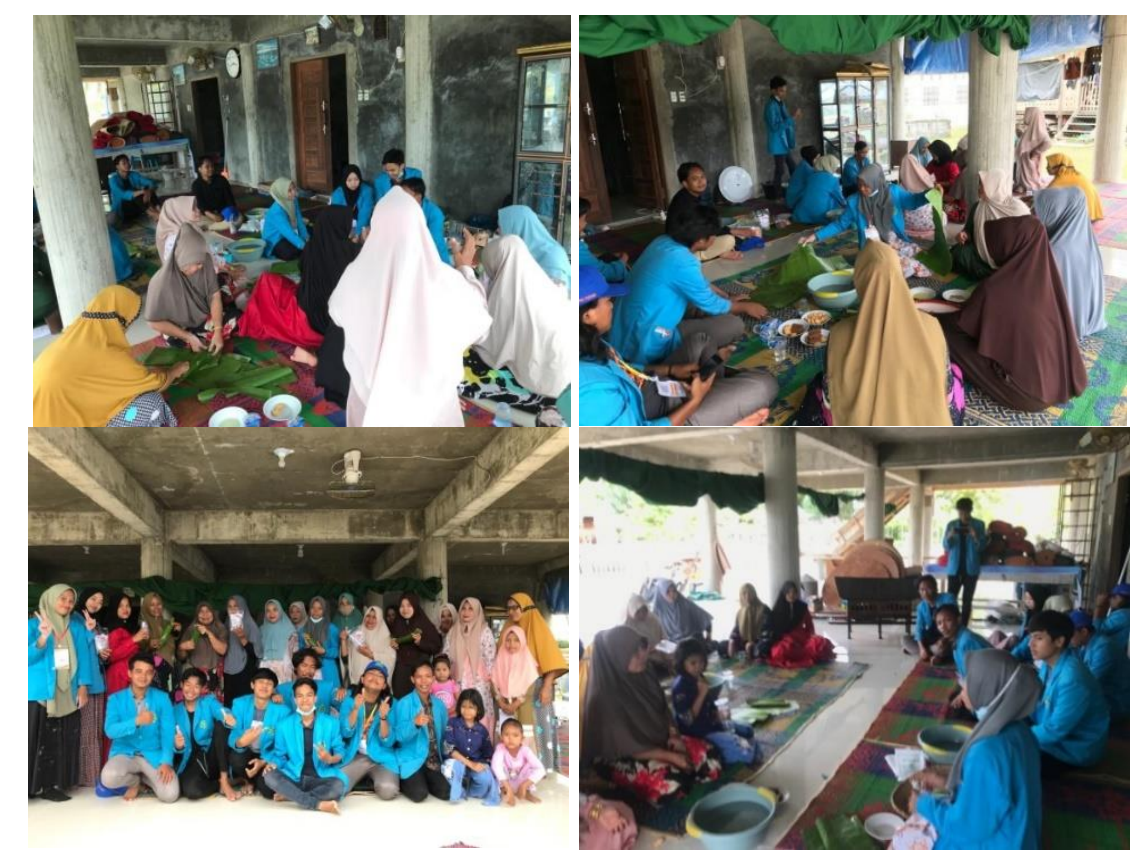

Gambar 3. Sosialisasi Pembuatan Kerupuk

\subsection{Program pendukung}

1. Pesisir mengajar

Program kerja ini dibuat dan dilaksanakan untuk meningkatkan semangat belajar dan memberikan materi tambahan terkait mata pelajaran di sekolah. Pesisir mengajar dilakukan 
bagi anak-anak yang berusia dibawah 14 tahun. Program ini dilaksanakan setiap hari jumat pada pukul $14.00 \mathrm{~s} / \mathrm{d}$ selesai. Pada program ini tercapai 35 orang anak-anak. Persentase untuk program ini adalah $100 \%$ yaitu dapat dikatakan berhasil atau terlaksana.

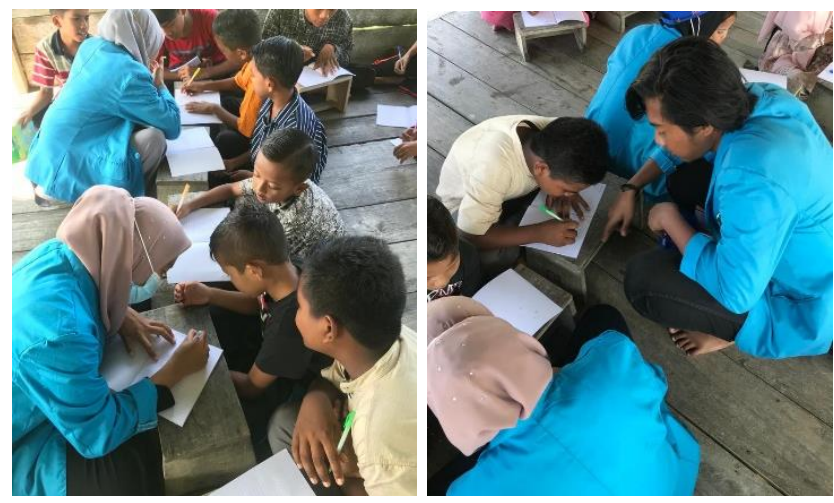

Gambar 4. Program Pesisir Mengajar

\section{Penanaman Mangrove}

Program kerja ini dibuat dilaksanakan untuk meningkatkan ekologi lahan basah dan penghijauan di desa Ulee Blang. Untuk program ini disediakan sebanyak 50 bibit mangrove dan 50 bibit mangrove terealisasikan dengan baik. Persentase pada program ini adalah $100 \%$ yaitu dapat dikatakan berhasil.

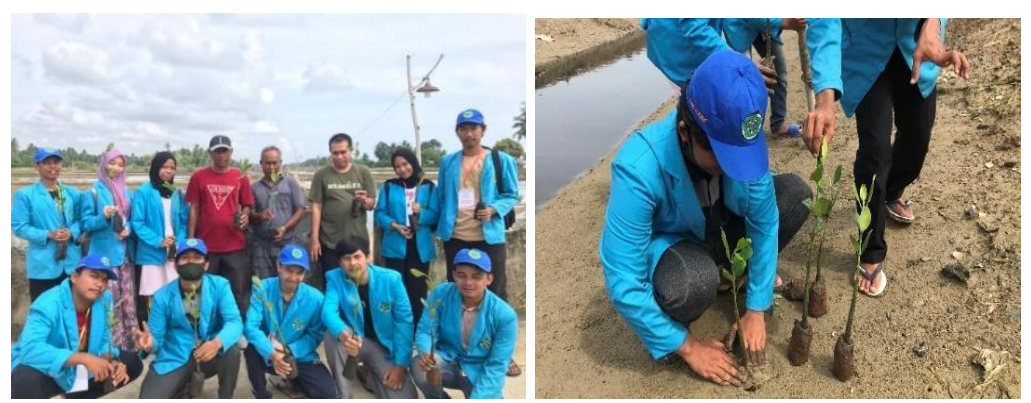

3. Pelatihan Microsoft Office

Gambar 5. Program Penanaman Mangrove

Pelatihan Microsoft office dibuat dilaksanakan untuk meningkatkan pengetahuan dibidang teknologi bagi anak-anak desa Ulee Blang. Pelatihan ini hanya mengajarkan 3 aplikasi yaitu Word, Excel Dan Powerpoint. Pada program ini tercapai 10 orang anak tingkat SMP. Persentase program ini adalah 100\% yaitu dapat dikatakan berhasil.

4. Desain Kemasan Produk Kerupuk Udang

Program ini diperuntukkan masyarakat. Yang di desain oleh mahasiswa KKN Tematik Unsam 2021 untuk label produk kerupuk udang nantinya. Tujuan nya sebagai upaya meningkatkan daya tarik penjualanan dan sebagai identitas produk desa Ulee Blang. Persentase untuk program ini adalah $100 \%$ yaitu terlaksana atau berhasil.

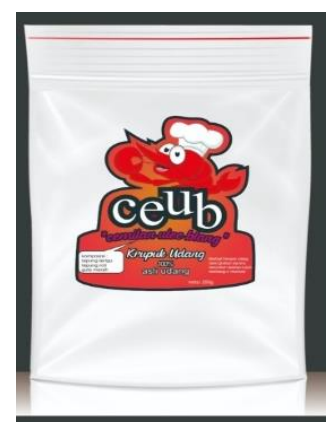

Gambar 6. Program Desain Kemasan Produk Kerupuk Udang 
5. Website Sistem Informasi \& Pemasaran Desa Ulee Blang

Program ini dibuat untuk memudahkan orang-orang dalam mengakses profil desa Ulee Blang. Melalui program ini Desa Ulee Blang dapat lebih dikenal oleh orang-orang. Program ini dapat terlaksana dengan baik dan berhasil. https://uleeblang.atjehtimur.com/ adalah link profil desa Ulee Blang.

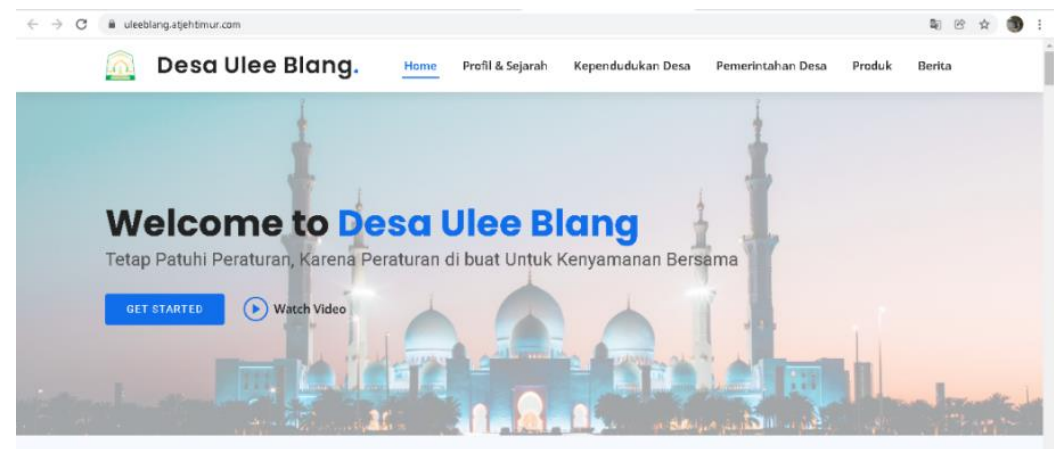

Gambar 7. Tampilan Website Desa Ulee Blang

6. Pembuatan Plang Penunjuk Arah

Program ini dibuat memudahkan masyarakat mengetahui arah menuju Desa Ulee Blang. Program ini dilakukan dengan cara merakit dan melukis dengan bahan papan dan kayu lalu di pasang di setiap dusun yang ada di Des Ulee Blang. Capaian ataupersentase pada program ini adalah $100 \%$ dimana program ini dapat dikatakan berhasil atau terealisasikan dengan baik.

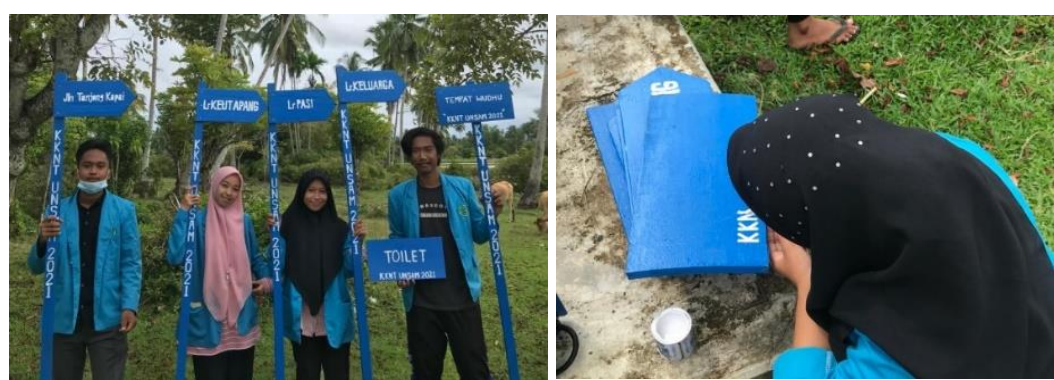

Gambar 8. Pembuatan Plang penunjuk Arah

7. Optimalisasi Mesin Kincir Air

Program ini dibuat untuk meningkatkan kadar oksigen didalam air dengan cara memastikan mesin agar tetap beroperasi dengan optimal atau dengan baik. Persentase pada program ini adalah $100 \%$ yaitu dapat dikatakan berhasil atau terlaksana.

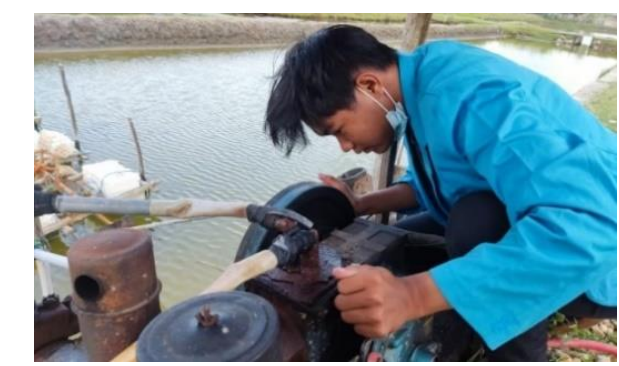

Gambar 9. Optimalisasi Mesin Kincir Air

\section{Pembuatan Rak Buku}

Program ini dibuat untuk menyimpan dan memudahkan dalam ruang belajar pada suatu organisasi pengajian yang ada di desa. Persentase pada program ini $100 \%$ atau dapat dikatakan berhasil terealisasikan dengan baik. 


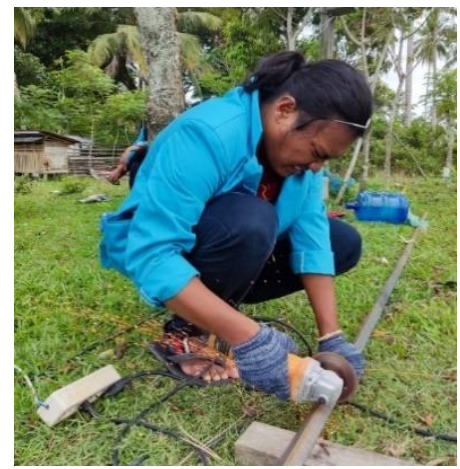

Gambar 10. Pembuatan Rak Buku

\section{Bakti Sosial}

Program ini merupakan kegiatan gotong royong bersama atau membantu masyarakat desa dalam kegiatan sosial berupa pembersihan lingkungan sekitar baik tempat ibadah, tempat pengajian dan kegiatan sosial lainnya seperti membantu acara pernikahan masyarakat desa. Persentase pada program ini $100 \%$ atau dapat dikatakan berhasil terealisasikan dengan baik.
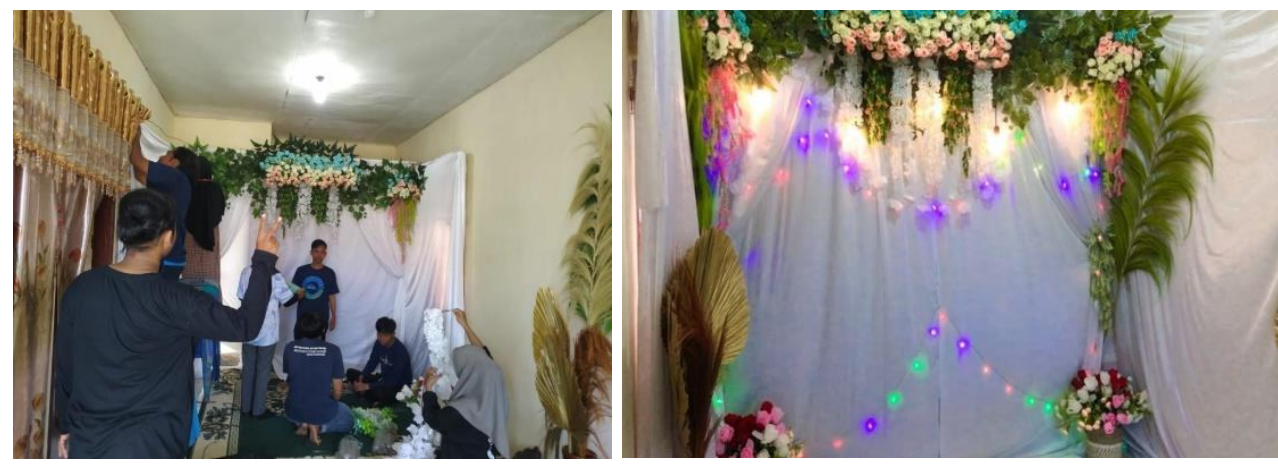

Gambar 11. Kegiatan Bakti Sosial

\section{Perayaan HUT RI ke-76}

Program ini di buat untuk memperingati hari kemerdekaan dan mempererat tali persaudaraantali persaudraan antar masyarakat dengan mengadakan berbagai perlombaan. Persentase pada program ini $100 \%$ atau dapat dikatakan berhasil terealisasikan dengan baik.

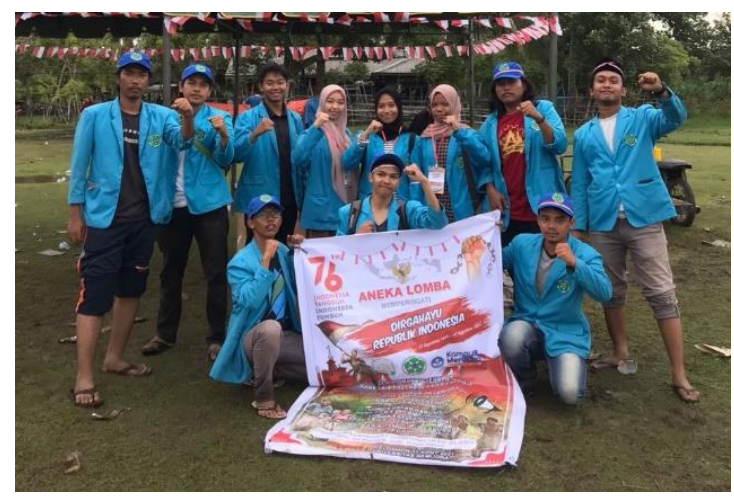

Gambar 12. Perayaan HUT RI ke-76

11. Perawatan Tugu Gampong Ulee Blang

Program ini dibuat untuk memudahkan msyarakat luar mengenali batasa Desa Ulee Blang dengan pengecatan ulang tugu Desa Ulee Blang. Persentase pada program ini $100 \%$ atau dapat dikatakan berhasil terealisasikan dengan baik. 

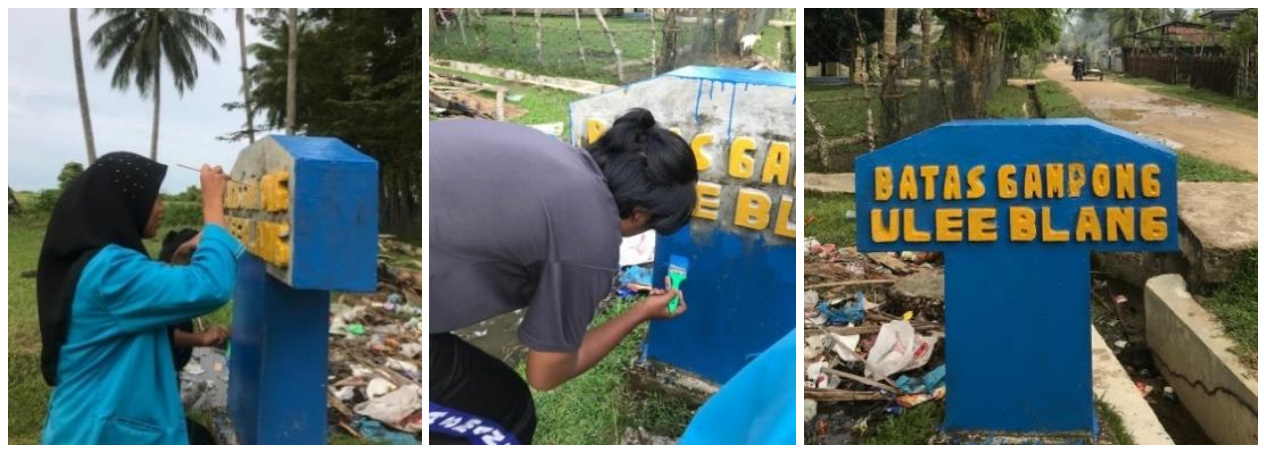

Gambar 13. Perawatan tugu gampong Ulee Blang

\section{Pemasangan Banner}

Program ini dibuat untuk memudahkan mengetahui letak lokasi Desa Ulee Blang dengan mendesain dan melakukan pemasangan banner. Persentase pada program ini $100 \%$ atau dapat dikatakan berhasil terealisasikan dengan baik.

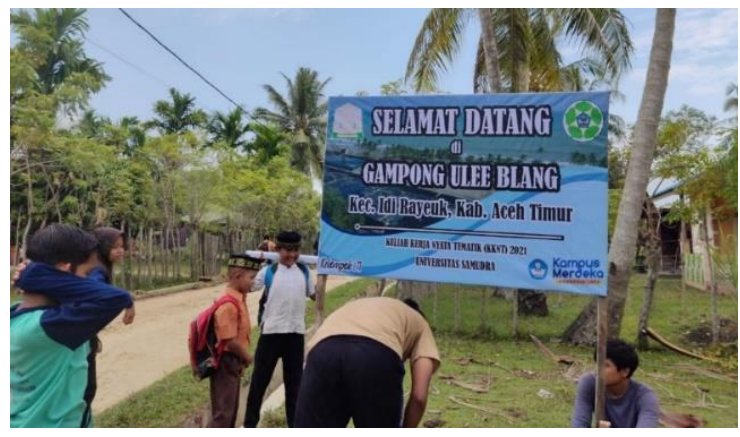

Gambar 14. Pemasangan Banner

\section{Pembuatan Cenderamata}

Program ini dibuat dengan memberikan kenang-kenangan pada perangkat Desa Ulee Blang berupa membuat foto-foto mahasiswa KKN dengan masyarakat yang dibingkaikan dan diserahkan kepada perangkat Desa Ulee Blang. Persentase pada program ini $100 \%$ atau dapat dikatakan berhasil terealisasikan dengan baik.
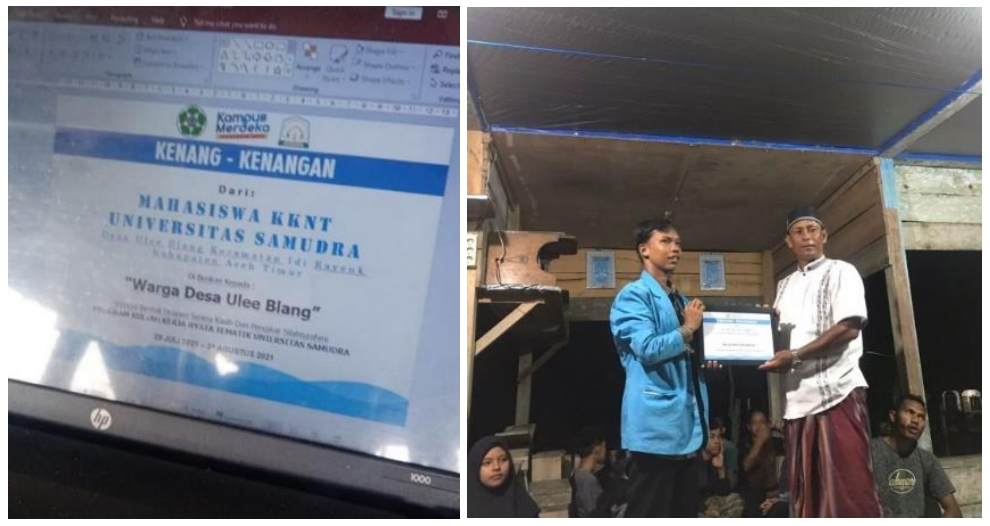

Gambar 15. Pembuatan Cenderamata

\section{KESIMPULAN}

Hasil pelaksanaan pengabdian masyarakat ini melalui KKN Tematik Unsam 2021, dapat ditarik kesimpulan berupa pengabdian masyarakat dengan KKN telah melaksanakan 13 program. 13 program ini meliputi berbagai pendidikan hingga teknologi, dimana program tersebut dapat sebagai upaya memecahkan masalah yang di hadapi masyarakat. Pelaksanaan 
program kerja mendapat respon positif dari perangkat desa dan masyarakat sehingga semua berjalan lancar meski memiliki banyak rintangan.

Program-progran kerja yang dilaksanakan juga menghasilkan luaran dan produk baik dari program utama maupun program pendukung. Diantaranya adalah untuk program utama berupa kerupuk udang khas Desa Ulee Blang. Sedangkan untuk prorgam pendukung berupa palang penunjuk arah, banner selamat datang, cenderamata, logo kemasan produk dan yang lainnya.

\section{UCAPAN TERIMA KASIH}

Ucapan terima kasih diberikan Allah SWT yang telah memberikan kemudahan dalam segala kegiatan ini. Ucapan terima kasih dan penghargaan setinggi-tingginya juga disampaikan kepada Fakultas Teknik Universitas Samudra yang telah mengadakan Kuliah Kerja Nyata (KKN) Tematik. Ucapan terima kasih juga disampaikan kepada Dosen Pembimbing Lapangan selaku yang membantu berjalannya program -program KKN, baik program utama maupun program pendukung. Terima kasih juga kepada masyarakat Desa Ulee Blang yang telah memberikan respon positif pada program KKN Tematik ini. Terima kasih juga kepada teman-teman sekelompok KKN atas kerja sama yang baik selama kegiatan ini.

\section{DAFTAR PUSTAKA}

Ii, B. A. B., Teori, A. D., Pengertian, T., \& Pembelajara, S. (2012). Kajian PustakaMolucca Medica, 11(April), 13-45. http://ojs3.unpatti.ac.id/index.php/moluccamed

Kurnia, M., Jaya, I., Jalil, A. R., Arya, N., \& Amin, S. (2020). KKN Tematik Pemberdayaan Masyarakat melalui Penerapan Teknologi Untuk Peningkatan Taraf Hidup Masyarakat Di Kecamatan Pulau Sembilan Kabupaten Sinjai. Jurnal Pengabdian Masyarakat Hasanuddin, 1(1), 1-9. https://journal.unhas.ac.id/index.php/jpmh/article/view/9579

Margolang, N. (2018). Pemberdayaan Masyarakat. Dedikasi: Journal of Community Engagment, I(2), 87-99. https://doi.org/10.31227/osf.io/weu8z

Sugiyani, Y., Perwitasari, E., Informasi, S., Informasi, T., Raya, S., Informatika, T., Informasi, T., \& Raya, S. (2018). Jurnal Pemberdayaan Packaging. Pemberdayaan Masyarakat Desa Melalui Pelatihan Packaging Produk Makanan Tradisional Yang Berdaya Jual Guna Meningkatkan Perekonomian Wilayah, 50-54.

Rerung, R. R., \& Pahmi. (2021). Pemberdayaan Potensi Masyarakat di Bidang Sosial, Pendidikan, dan Teknologi dalam Meningkatkan Sumber Daya Manusia di Desa Margaluyu. Jurnal Pengabfi, 1(1), 1-8.

Sudarwati, Bagus, Cantika, Cikal, Choirul, Fully, Hafid, Hanung, Lukiyanto, Rizal, \& Sylivia. (2020). Melalui Kkn Tematik Covid-19 Uniba Tahun 2020 Membudayakan Hidup Sehat Di Era New Normal Sebagai Upayamelawan Covid-19.02(01), 43-49.

Umar, A. U. A. Al, Savitri, A. S. N., Pradani, Y. S., Mutohar, \& Khamid, N. (2021). Peranan Kuliah Kerja Nyata Sebagai Wujud Pengabdian Kepada Masyarakat Di Tengah Pandemi COVID-19 (Studi Kasus Iain Salatiga KKN 2021). E-Amal Jurnal Pengabdian Kepada Masyarakat, 1(1), 39-47

Kerja, K., \& Kkp, P. (n.d.). Panduan dan jurnal. Panduan Dan Jurnal Kuliah Kerja Nyata, 1-38.

Aliyyah, R. R., Rahmawati, R., Safitri, J., \& ... (2021). Kuliah Kerja Nyata: Pengabdian Kepada Masyarakat Melalui Kegiatan Pendampingan Pendidikan. JMM (Jurnal ..., 5(2), 663-676. https://www.researchgate.net/profile/Rusi-Rusmiati-

Saharuddin, S. (2017). Pengabdian KKN-PPM Desa Wonorejo Kecamatan Mangkutana Kabupaten Luwu Timur. RESONA: Jurnal Ilmiah Pengabdian Masyarakat, 1(1), 20-25. https://doi.org/10.35906/jipm01.v1i1.243 